\title{
Mental Health Problems among University Palestinian Students
}

\author{
Abdelaziz M Thabet ${ }^{1 *}$ and Taysir Abdalla ${ }^{2}$ \\ ${ }^{1}$ Emeritus Professor of Psychiatry, Al Quds University, School of Public-Consultant Psychiatrist at Child and Family Training and Counseling Center, \\ Palestine
}

${ }^{2}$ Professor of Psychology, Al Quds University, Palestine

Submission: January 16, 2018; Published: March 22, 2018

*Corresponding author: Abdelaziz M Thabet, Emeritus Professor of Psychiatry, Al Quds University, School of Public-Consultant Psychiatrist at Child and Family Training and Counseling Center, Palestine, Email: abdelazizt@hotmail.com

\begin{abstract}
Aim: The aim of this study is to explore the prevalence of mental health problems among Palestinians university students.

Method: The sample consisted of randomly selected 216 Palestinian university students enrolled in two universities in Gaza Strip (Al-AlAzhar and Islamic University) and one university in West Bank (Al Quds university of Jerusalem) at the second semester of the academic year 2004-2005. Eighty-seven of the participants (40.3\%) were males and 129 (59.7\%) were females. Age ranged from 17 to 30 years. Mean age was 20.4 years $(\mathrm{SD}=1.8)$. We used two questionnaires; a predesigned socio- demographic sheet and General Health Quesionnare-28 items.

Results: The study showed than mean GHQ-28 was 8.71 , somatization mean was 1.74 , anxiety mean was 2.87 , social dysfunction mean was 1.94, and depression mean was 2.16 . The result showed that $69.4 \%$ were rated as psychiatric morbidity cases and need further investigation, while $30.6 \%$ were not cases. No statistically significant differences in sex of students and GHQ-28 and subscales. Students from West Bank reported more anxiety than those in Gaza Strip. No other statistically differences in total GHQ28 and other subscales. Moreover, there were no statistically significant differences in GHQ-28 and subscales according to type of residence (city, village, camp). Students from Al Azhar university scored more in total GHQ, anxiety, and more depression than those from Islamic and Al Quds university.

Clinical Implications: Our findings that university students had high rate of mental health problems Such findings highlight the need for establishing counselling centers in the universities to help students on overcoming their death anxiety and obsession. Also, there is needed for training courses for students in causes and ways of intervention with such problems.
\end{abstract}

Keywords: Mental health; University; Students; Gaza strip; West bank

\section{Introduction}

The mental health of university students is of increasing concern globally. In the United States, with a national epidemiological study reporting that almost half the college students surveyed met the criteria for a psychiatric disorder in the past year although less than $25 \%$ sought treatment, and that the rate for college students was not significantly different from nonstudents Blanco et al. [1]. Locally in Palestine et al. [2] in study a sample consisted of 392 students from the four universities in Gaza Strip. The results showed that $166(42.3 \%)$ had moderate anxiety, and $62(15.8 \%)$ of had severe anxiety. While $146(37.2 \%)$, had moderate depression, and $12(3.1 \%)$ of them were had severe depression. The emerging findings from the literature indicate that community college students are vulnerable to mental health disorder Francis et al. [3], Katz et al. [4]. In the United Kingdom, the UK Psychiatric Morbidity Survey reported significant increases in anxiety and depression in young people aged 1624 but could not identify the students in this population (Singleton, Bumpstead, O-Brien, Lee \& Meltzer, 2001). In a study Macaskill [5] of total
1197 undergraduate students in a very large modern university in the north of England. The overall incidence of psychiatric caseness in the total sample was $17.3 \%$. The caseness for women was $24.2 \%$ while for men it was $12.56 \%$, a significant difference. There was no significant effect of course being studied. Examining the caseness data set separately for anxiety and depression showed that for anxiety, $97.1 \%$ of the total overall GHQ cases met anxiety caseness criteria, while the figure was lower for depression with $46.4 \%$ of the total overall GHQ caseness scores meeting depression caseness criteria.

Few studies were conducted in the area to evaluate the mental health of university students. Furthermore, Juma et al. [6] in study of 399 Palestinian university students from main four universities in Gaza Strip. The study showed that $9.5 \%$ of males and $12 \%$ of females had severe depression. No gender differences. Also, $10.3 \%$ of males and $13.8 \%$ of females had anxiety. No statistically significant differences in anxiety according to gender. Thabet et al. [7] in study a sample consisted of randomly selected 399 
university students enrolled from the main four universities in Gaza Strip. The study showed that anxiety trait mean was 36.22 and anxiety state mean was 46.62 . Mosallam et al. [8] in study of 392 university students enrolled from the main four universities in Gaza Strip. The study showed that $28 \%$ had severe anxiety to very severe anxiety. There was no significant difference in anxiety according to gender. However, there was significant difference in anxiety toward students enrolled in Al Azhar University than the other three universities students according to the university or college type. The study showed that $14.2 \%$ of university students had moderate to severe depression. The study showed no significant gender difference in depression and according to university enrollment.

More recently, Gorbena et al. [9] in study of total of 4461 university students completed a health and well-being survey, including the GHQ-12, Ryff psychological well-being scale and a scale of 25 life stressors. Indexes of number and severity of difficulties in relationships were calculated with 10 items including romantic partners, friends, family, and classmates. Results Correlations were significant. Logistic regression showed a risk effect for all stressors with OR values above 1.32. Overall perceived severity had the highest and amongst the 10 stressors, gender related abuse/violence was also the highest. Positive relations showed a protective effect. Since the students play an important role in the economic and social development programs and management of community affairs, paying attention to their issues in different dimensions, particularly their mental aspect should not be neglected. Therefore, in this research, we decided to study the mental health among university students in Palestine.

\section{Method}

\section{Participants}

Participants were 216 Palestinian university students enrolled from two universities in Gaza Strip (Al-Al-Azhar and Islamic University) and one university from West Bank (Al Quds Results university of Jerusalem). Eighty-seven of the participants (40.3\%) were males and 129 (59.7\%) were females.

\section{Measures}

A predesigned socio- demographic sheet: This questionnaire included; gender, age, name of the university, place of residence, and marital status. The Arabic Scale of General Health Questionnaire-28 Goldberg et al. [10,11], (Thabet \& Vostanis, 2005) Students mental health ratings were based on the General Health Questionnaire (GHQ-28). It covers severe depression and suicidal risk, anxiety and insomnia, social dysfunction, and somatic symptoms (59). Emphasis is on changes in condition, so items compare the present mental state to the person's normal mental health status. GHQ-28 scores above the cut-off of $4 / 5$ are considered to be possible psychiatric 'cases'. This scale had been validated in Arabic culture and showed reliability and validity. The internal consistency of the scale calculated using Cronbach's alpha, was $\alpha=0.91$ and split half was 0.88 Thabet et al. [6]. In this study the Cronbach's alpha was $\alpha=0.88$ and split half was 0.74 .

Data Collection Procedures: The researcher implemented structured questionnaires to collect data directly from universities students. The permission was received from the three universities mentioned before. The researcher collected data by trained field workers through coordinated the public relation offices, to the students in the three universities, either in classroom settings or outside classroom in two weeks in the second semester of the Academic year 2004/2005. Each student has completed 2 scales on 15 minutes.

Statistical Analysis: Data was entered and analysed using the Statistical Package for Social Sciences (SPSS) software version 20 computer program. Between-group comparison was explored by independent t-test, and more than two variables we used One-way ANOVA tests. Associations between different continuous variables were tested by Pearson correlation coefficient.

\section{Socio-Demographic of the Study Sample}

Table 1: Socio-demographic of the study sample $(\mathrm{N}=216)$.

\begin{tabular}{|c|c|c|}
\hline & $\mathbf{N}$ & $\%$ \\
\hline \multicolumn{3}{|l|}{ Sex } \\
\hline Male & 87 & 40.3 \\
\hline Female & 129 & 59.7 \\
\hline Total & 216 & 100.0 \\
\hline mean $=20.41(S D=1.76)$ & & \\
\hline \multicolumn{3}{|c|}{ Site of residence } \\
\hline Gaza & 102 & 47.2 \\
\hline West bank & 114 & 52.8 \\
\hline Name of university & 216 & 100.0 \\
\hline Islamic university & 47 & 21.8 \\
\hline Al Azhar university & 55 & 25.5 \\
\hline
\end{tabular}




\section{JOJ Nursing \& Health Care}

\begin{tabular}{|c|c|c|}
\hline Al Quds university Jerusalem & 114 & 52.8 \\
\hline \multicolumn{3}{|c|}{ Marital status } \\
\hline Single & 197 & 91.2 \\
\hline Married & 18 & 8.3 \\
\hline Divorced & 1 & .5 \\
\hline Place of residence & 216 & 100.0 \\
\hline North west bank & 19 & 8.8 \\
\hline Middle West Bank & 33 & 15.3 \\
\hline South West Bank & 33 & 15.3 \\
\hline Jerusalem & 29 & 13.4 \\
\hline Gaza Strip & 102 & 47.2 \\
\hline \multicolumn{3}{|c|}{ Type of residence } \\
\hline City & 108 & 50.0 \\
\hline Village & 82 & 38.0 \\
\hline Camp & 26 & 12.0 \\
\hline
\end{tabular}

Participants were 216 Palestinian university students enrolled from two universities in Gaza Strip (Al-Al-Azhar and Islamic University) and one university from West Bank (Al Quds

\section{Psychological Symptoms of Women using GHQ-28}

Table 2: Psychological symptoms according to GHQ-28.

\begin{tabular}{|c|c|c|}
\hline & Worse than usual/worse & Better than usual/ usual \\
\hline \multirow[t]{2}{*}{$\begin{array}{l}\text { A1. Been feeling perfectly well and in good } \\
\text { health? }\end{array}$} & 86.1 & 13.9 \\
\hline & No/less than usual & More/much more than usual \\
\hline A2. Been feeling the need of a good tonic? & 76.9 & 23.1 \\
\hline A3. Been feeling run down and out of sorts? & 57.4 & 42.6 \\
\hline A4. Felt that you are ill? & 76.7 & 21.3 \\
\hline A5. Been getting any pains in your head? & 69.9 & 30.1 \\
\hline $\begin{array}{l}\text { A6. Been getting a feeling of tightness or } \\
\text { pressure in your head? }\end{array}$ & 68.1 & 31.9 \\
\hline A7. Been having hot or cold spells? & 85.2 & 14.8 \\
\hline B1. Lost much sleep over worry? & 69 & 31 \\
\hline $\begin{array}{l}\text { B2. Had difficulty staying a sleep once you are } \\
\text { off? }\end{array}$ & 60.6 & 39.4 \\
\hline B3. Felt constantly under strain? & 50.9 & 49.1 \\
\hline B4. Been getting edgy and bad-tempered? & 45.8 & 54.2 \\
\hline $\begin{array}{l}\text { B5. Been getting scared or panicky for no good } \\
\text { reason? }\end{array}$ & 79.2 & 20.8 \\
\hline B6. Found everything getting on top of you? & 44.9 & 55.1 \\
\hline $\begin{array}{l}\text { B7. Been feeling nervous and strung-up all the } \\
\text { time? }\end{array}$ & 56.5 & 43.5 \\
\hline $\begin{array}{l}\text { D1. Been thinking of yourself as a worthless } \\
\text { person? }\end{array}$ & 70.4 & 29.6 \\
\hline D2. Felt that life is entirely hopeless? & 70.8 & 29.2 \\
\hline D3. Felt that life isn't worth living? & 66.2 & 33.8 \\
\hline $\begin{array}{l}\text { D4. Found at times you couldn't do anything } \\
\text { because your nerves were too bad? }\end{array}$ & 73.1 & 26.9 \\
\hline
\end{tabular}

university of Jerusalem). Eighty-seven of the participants (40.3\%) were males and 129 (59.7\%) were females. Age ranged from 17 to 30 years, mean age was 20.4 years $(S D=1.8)$ (Table 1$)$. 


\begin{tabular}{|c|c|c|}
\hline $\begin{array}{l}\text { D5. Found yourself wishing you were dead and } \\
\text { away from it all? }\end{array}$ & 79.6 & 20.4 \\
\hline & More/much more than usual & No/less than usual \\
\hline \multirow[t]{2}{*}{$\begin{array}{l}\text { D6. Been managing to keep yourself busy and } \\
\text { occupied? }\end{array}$} & 80.6 & 19.4 \\
\hline & Faster than usual & Much less than usual \\
\hline \multirow[t]{2}{*}{ D7. Been taking longer over the things you do? } & 63.4 & 36.6 \\
\hline & Satisfied & Satisfied much less than before \\
\hline \multirow[t]{2}{*}{$\begin{array}{l}\text { C1. Been satisfied with the way you've carried } \\
\text { out your tasks? }\end{array}$} & 82.9 & 16.7 \\
\hline & More than usual & Much less than usual \\
\hline $\begin{array}{l}\text { C2. Felt on the whole you were doing things } \\
\text { well? }\end{array}$ & 60.2 & 39.4 \\
\hline $\begin{array}{l}\text { C3. Felt that you are playing a useful part in } \\
\text { things? }\end{array}$ & 69.9 & 30.1 \\
\hline $\begin{array}{l}\text { C4. Felt capable of making decisions about } \\
\text { things? }\end{array}$ & 55.1 & 44.9 \\
\hline \multirow[t]{2}{*}{$\begin{array}{l}\text { C5. Been able to enjoy your normal day-to-day } \\
\text { activities? }\end{array}$} & 50.9 & 49.1 \\
\hline & Never/I don't think & Much more/more than usual \\
\hline \multirow[t]{2}{*}{$\begin{array}{l}\text { C6. Thought of the possibility that you might } \\
\text { make away with yourself? }\end{array}$} & 70.4 & 29.6 \\
\hline & Never/I don't think & Much more/more than usual \\
\hline $\begin{array}{l}\text { C7. Found the idea of taking your own life kept } \\
\text { coming into your mind? }\end{array}$ & 93.1 & 6.9 \\
\hline
\end{tabular}

As shown in Table 2, $13.9 \%$ said they had feeling of perfectly well and in good health, while 6.95 said the idea of taking their own life kept coming into their minds mind? 55.1\% said that everything getting on top of them much and more than usual, $54.2 \%$ getting edgy and bad-tempered, $49.1 \%$ felt constantly under strain, $43.5 \%$ felt nervous and strung-up all the time.

\section{Means and Standard Deviation of the GHQ-28}

The study showed than mean GHQ-28 was 8.71 (SD = 6.46), somatization mean was $1.74(\mathrm{SD}=2.01)$, anxiety mean was 2.87 ( $\mathrm{SD}=2.29)$, social dysfunction mean was $1.94(\mathrm{SD}=1.76)$, and depression mean was $2.16(\mathrm{SD}=1.94)$ (Table 3).

Table 3: Means and standard deviation of the GHQ-28.

\begin{tabular}{|c|c|c|c|c|c|}
\hline & N & Min. & Max. & Mean & SD \\
\hline Total GHQ & 216 & 0 & 28 & 8.71 & 6.46 \\
\hline Anxiety & 216 & 0 & 7 & 1.74 & 2.01 \\
\hline Somatization & 216 & 0 & 7 & 2.87 & 2.29 \\
\hline $\begin{array}{c}\text { Social } \\
\text { dysfunction }\end{array}$ & 216 & 0 & 7 & 1.94 & 1.76 \\
\hline $\begin{array}{c}\text { Depression } \\
\text { Depres| }\end{array}$ & 216 & 0 & 12 & 2.16 & 1.94 \\
\hline
\end{tabular}

\section{Prevalence of mental health problems}

Using the previous cut-off point of the GHQ-28 (4/5), the result showed that $69.4 \%$ were rated as psychiatric morbidity cases and need further investigation, while $30.6 \%$ were not cases (Table 4).

Table 4: Psychiatric cases according to GHQ-28.

\begin{tabular}{|c|c|c|}
\hline & No. & $\%$ \\
\hline $\begin{array}{c}\text { Non psychiatric } \\
\text { morbidity }\end{array}$ & 66 & 30.6 \\
\hline Psychiatric morbidity & 150 & 69.4 \\
\hline Total & 216 & 100.0 \\
\hline
\end{tabular}

Differences in GHQ-28 and Subscales and other Sociodemographic Variables

Differences in Mean and Standard Deviation of GHQ-28 and Subscales and Sex of Student: Independent t test showed no statistically significant differences in sex of students and GHQ28 and subscales (Table 5). 
Table 5: Differences in mean and standard deviation of GHQ-28 and subscales and sex of student.

\begin{tabular}{|c|c|c|c|c|c|c|c|}
\hline \multicolumn{2}{|c|}{ gender } & \multirow{2}{*}{$\begin{array}{l}\mathbf{N} \\
87 \\
\end{array}$} & \multirow{2}{*}{$\begin{array}{c}\text { Mean } \\
8.95 \\
\end{array}$} & \multirow{2}{*}{$\begin{array}{c}\text { Std. Deviation } \\
6.78\end{array}$} & \multirow{2}{*}{$\begin{array}{c}\begin{array}{c}\text { Mean } \\
\text { differences }\end{array} \\
.40 \\
\end{array}$} & \multirow{2}{*}{$\begin{array}{c}\mathbf{t} \\
.45 \\
\end{array}$} & \multirow{2}{*}{$\begin{array}{l}\mathbf{p} \\
.65 \\
\end{array}$} \\
\hline & Male & & & & & & \\
\hline torat & Female & 129 & 8.55 & 6.26 & & & \\
\hline \multirow{2}{*}{ somatization } & Male & 87 & 1.85 & 2.13 & .18 & .66 & .51 \\
\hline & Female & 129 & 1.67 & 1.93 & & & \\
\hline \multirow{2}{*}{ anxiety } & Male & 87 & 2.99 & 2.36 & .19 & .60 & .55 \\
\hline & Female & 129 & 2.80 & 2.24 & & & \\
\hline \multirow{2}{*}{$\begin{array}{c}\text { social } \\
\text { dysfunction }\end{array}$} & Male & 87 & 2.13 & 1.84 & .32 & 1.32 & .19 \\
\hline & Female & 129 & 1.81 & 1.69 & & & \\
\hline \multirow{2}{*}{ depression } & Male & 87 & 1.99 & 1.79 & -.29 & -1.08 & .28 \\
\hline & Female & 129 & 2.28 & 2.04 & & & \\
\hline
\end{tabular}

Differences in Mean and Standard Deviation of GHQ-28 and Subscales and Place of Residence of Student: Independent $\mathrm{t}$ test showed that students from West Bank reported more anxiety than those in Gaza Strip $(\mathrm{t}=(214),-2.36, \mathrm{p}=0.02)$. No other statistically differences in total GHQ28 and other subscales. Moreover, there were no statistically significant differences in GHQ-28 and subscales according to type of residence (city, village,

Table 6: Differences in mean and standard deviation of GHQ-28 and subscales and place of residence of student.

\begin{tabular}{|c|c|c|c|c|c|c|}
\hline \multicolumn{2}{|c|}{ Site of study } & $\mathbf{N}$ & Mean & Std. Deviation & $\mathbf{t}$ & $\mathbf{p}$ \\
\hline \multirow{2}{*}{ Total GHQ } & Gaza & 102 & 8.17 & 6.59 & -1.18 & .24 \\
\hline & West bank & 114 & 9.20 & 6.33 & & \\
\hline \multirow{2}{*}{ Somatization } & Gaza & 102 & 1.55 & 2.00 & -1.33 & .19 \\
\hline & West bank & 114 & 1.91 & 2.02 & & \\
\hline \multirow{2}{*}{ Anxiety } & Gaza & 102 & 2.49 & 2.27 & -2.36 & .02 \\
\hline & West bank & 114 & 3.22 & 2.26 & & \\
\hline \multirow{2}{*}{ Social dysfunction } & Gaza & 102 & 1.82 & 1.79 & -.88 & .38 \\
\hline & West bank & 114 & 2.04 & 1.73 & & \\
\hline \multirow{2}{*}{ Depression } & Gaza & 102 & 2.30 & 2.05 & 1.01 & .31 \\
\hline & West bank & 114 & 2.04 & 1.84 & & \\
\hline
\end{tabular}

\section{Discussion}

The study showed than mean GHQ-28 was 8.71, somatization mean was 1.74 , anxiety mean was 2.87 , social dysfunction mean was 1.94 , and depression mean was 2.16. The result showed that $69.4 \%$ were rated as psychiatric morbidity cases and need further investigation, while $30.6 \%$ were not cases. No statistically significant differences in sex of students and GHQ-28 and subscales. Students from West Bank reported more anxiety than those in Gaza Strip. No other statistically differences in total GHQ28 and other subscales. Moreover, there were no statistically significant differences in GHQ-28 and subscales according to type of residence (city, village, camp). Our study showed that students enrolled at Al Azhar university scored more in total GHQ, anxiety, and more depression than those from Islamic and Al Quds university. Our findings were inconsistent with other studies which found less rate of anxiety and depression. In the largest camp) (Table 6). One -way ANOVA test showed was conduct. Post hoc using Tukey HSD test showed that students from Al Azhar university scored more in total GHQ $(\mathrm{F}(213 / 2)=5.53, \mathrm{p}<0.001)$, anxiety $(\mathrm{F}(213 / 2)=10.58, \mathrm{p}<0.001)$, and more depression ( $\mathrm{F}$ $(213 / 2)=7.43, p<0.001)$ than those from Islamic and Al Quds university. psychometricstudy of studentmental distress to date (Adlaf, 2001), a prevalence of elevated psychological distress were found in $30 \%$ of 7,526 randomly sampled undergraduate students, attending 16 different universities in Canada. Among the 1st-year students, the prevalence of elevated psychological distress was 34\%. Compared to data from the general population in Canada, the frequency of elevated distress was significantly higher and nearly the double of a non-student population. Furthermore, (Nerdrum, 2006) in study of 1750 undergraduate students that had begun their education at one of the seven faculties at Oslo University College. Students were interviewed with the General Health Questionnaire (GHQ)-12 items. The percentage of study participants that have been classified as cases was $21.1 \%$ when using the $4+$ threshold. The GHQ case mean score in the total sample was 2.08 , while the GHQ Likert mean score was 10.63. In this study, women reported a significantly higher level of psychological distress than men. Those born outside Norway reported a significantly higher level 
of distress compared to those who were born in Norway. Those reporting that their father's educational achievement was at the primary level reported significantly higher psychological distress compared to those reporting that their father's educational level was higher. In Arab countries, similar studies conducted in Egypt universities reported other figures; in Menoufiya University, the prevalence of depression and anxiety, was $63.6 \%$ and $78.4 \%$ respectively Abdallah et al. [12]. Depression in Alexandria University; $43.9 \%$ and $57.9 \%$ of medical students were suffering from anxiety and depression respectively Ibrahim et al. [13]. Another study conducted in Mansoura University among medical students has reported lower figures; prevalence of depressive and anxious symptoms was $28.3 \%$ and $21.2 \%$ Amir et al. [14]. Our findings are also similar to what is reported in other countries; in Pakistan, a prevalence of $70 \%$ anxiety and depression was reported among medical students Khan et al. [15]. More recently others found similar rate of mental health problems in university students, Abdel Wahed et al. [16] in study of a cross-sectionalquestionnaire based study of 442 medical students in Fayoum University found the prevalence of depression and anxiety was detected among $60.2 \%$ and $64.3 \%$ of medical students More recently others found lower rates of mental health problems, Torres et al. [17] in study of a sample of 1092 students (53.7\% women; mean age $=18.3$ years) who were recruited from the Technical Particular University of Loja (Ecuador). It was found that $6.2 \%$ of students met the criteria for diagnosis of a major depressive episode, $0.02 \%$ met criteria for generalized anxiety disorder, $2.2 \%$ for panic disorder, $32.0 \%$ were at risk of an eating disorder and 13.1were at risk for suicide [18].

\section{Conclusion and Recommendation}

A substantial proportion of Palestinian university students are suffering from psychological disorders. The prevalence is equal in both females and males. Counselling and preventive mental health services should be an essential part of the routine investigation of university students. Actions should be taken to encourage the students to seek help on exposure to distress. Further studies should be done to identify different sources and causes of stress especially related to academic and educational factors, and the effect of different intervention measures to avoid or cope with the psychological effect of the life tension.

\section{References}

1. Blanco C, Okuda M, Wright C, Hasin DS, Grant BF, et al. (2008) Mental health of college students and their non-college-attending peers: Results from the National Epidemiologic Study on Alcohol and Related Conditions. General Psychiatry 65(12): 1429-1437.
2. Lubad I, Thabet AA (2009) The impact of Siege on Prevalence of Depression and Anxiety Disorder among Universities Students. Arabpsynet E Journal 24: 56-66.

3. Francis PC, Abbassi A (2010) Ethical issues and considerations for working with community college students with severe and persistent mental disorders. Community College Journal of Research and Practice 34(5): 423-437.

4. Katz DS, Davison K (2014) Community college student mental health: A comparative analysis. Community College Review 42(4): 307-326.

5. Macaskill A (2013) The mental health of university students in the United Kingdom. BritishJournal of Guidance\&Counselling41(4):426-441.

6. Juma A, Thabet AA (2015) Relationship between stressors due to siege of Gaza Strip on anxiety, depression and coping strategies among university students. Arab Journal of Psychiatry 26(1): 39-48.

7. Thabet AA, Abusultan S (2016) War trauma, anxiety, and resilience among university students in the Gaza Strip. Clinical Psychiatry 2(4): 19.

8. Aysheh Yousef Mosallam, Thabet AA (2016) Coping with Stressful Life Events and Mental Health Disorders among University Students. BAO] Psychology 3(1): 011

9. Gorbena S, Penas P, Calvete E, Crespo I, Iraurgi I (2017) Risk of mental disorders and difficulties or conflict in relationships in young adults. $5^{\text {th }}$ European Congress of Psychiatry/European Psychiatry 41S S69-S105.

10. Goldberg D, Williams P (1991) A user's guide to the General Health Questionnaire. NFER, Nelson, London.

11. Goldberg DP, Gater R, Sartorius N, Ustun TB, Piccinelli M, et al. (1997) The validity of two versions of the GHQ in the WHO study of mental illness in general health care. Psychological Medicine 27: 191-197.

12. Abdallah AR, Gabr HM (2014) Depression, anxiety and stress among first year medical students in an Egyptian public university. Int Res] Med Med Sci 2(1): 11-19.

13. Ibrahim MB, Abdelreheem MH (2015) Prevalence of anxiety and depression among medical and pharmaceutical students in Alexandria University. Alexandria J Med 51(2): 167-173.

14. Amir M, El Gillany AH (2010) Self-reported depression and anxiety by students at an Egyptian Medical School. J Pakist Psych Soc (JPPC) 7(2): 71.

15. Khan MS, Mahmood S, Badshah A, Ali SU, Jamal Y (2006) Prevalence of depression, anxiety and their associated factors among medical students in Karachi, Pakistan. J Pak Med Assoc 56(12): 583-586.

16. Abdel Wahed W, Hassan SK (2017) Prevalence and associated factors of stress, anxiety and depression among medical Fayoum University students. Alexandria Journal of Medicine 53: 77-84.

17. Torres C, Otero P, Bustamante B, Blanco V, Olga Díaz O, et al. (2017) Mental Health Problems and Related Factors in Ecuadorian College Students. Int J Environ Res Public Health 14: 530.

18. El Gilany AH, Amr M, Hammad S (2008) Perceived stress among male medical students in Egypt and Saudi Arabia: effect of sociodemographic factors. Ann Saudi Med 28(6): 442-448. 
This work is licensed under Creative Commons Attribution 4.0 License DOI: 10.19080/JOJNHC.2018.07.555704

\section{Your next submission with Juniper Publishers will reach you the below assets}

- Quality Editorial service

- Swift Peer Review

- Reprints availability

- E-prints Service

- Manuscript Podcast for convenient understanding

- Global attainment for your research

- Manuscript accessibility in different formats

( Pdf, E-pub, Full Text, Audio)

- Unceasing customer service

Track the below URL for one-step submission https://juniperpublishers.com/online-submission.php 